\title{
Common Behavior in the Practice of Democracy in Africa
}

\author{
Coulibaly Yacouba1, Traore Sanibe Emmanuel ${ }^{2}$ \\ ${ }^{1}$ School of Marxism, Central China Normal University, Wuhan, China \\ ${ }^{2}$ Institute of political Science (I.P.S), Central China Normal University, Wuhan, China \\ Email: bayacoulib@yahoo.fr, traoresanibeemmanuel@yahoo.fr
}

How to cite this paper: Yacouba, C., \& Emmanuel, T. S. (2017). Common Behavior in the Practice of Democracy in Africa. Open Journal of Political Science, 7, 17-24. http://dx.doi.org/10.4236/ojps.2017.71002

Received: October 17, 2016

Accepted: November 29, 2016

Published: December 2, 2016

Copyright $\odot 2017$ by authors and Scientific Research Publishing Inc. This work is licensed under the Creative Commons Attribution International License (CC BY 4.0).

http://creativecommons.org/licenses/by/4.0/ c) (i) Open Access

\begin{abstract}
Africa is a vast continent with such a diverse and complex culture, which requires us to be careful in our language as we discuss and debate about the continent. Thus, the question of democracy in Africa is nowadays a debate that divides very schematically the political scientists. For instance, it is when it comes to the identification of the beginning of democratization in the continent, the description of the level of advancement in the democratic practice or even the nature of democracy that the differences arise. Although one thing remains undisputable: the practice of democracy in Africa suffers from many problems such as, misunderstanding, violence, problem of adaptation, multiple numbers of political party. Africa is a vast continent with such a diverse and complex culture, which requires us to be careful in our language as we discuss and debate about the continent. Thus, the question of democracy in Africa is nowadays a debate that divides very schematically the political scientists. For instance, it is when it comes to the identification of the beginning of democratization in the continent, the description of the level of advancement in the democratic practice or even the nature of democracy that the differences arise. However, one thing remains undisputable: the practice of democracy in Africa suffers from many problems such as, misunderstanding, violence, problem of adaptation, multiple numbers of political party.
\end{abstract}

\section{Keywords}

Common, Practice, Democracy, Africa

\section{Introduction}

The choice of this topic is far from being an accident; it is intended to solve a real concern which is the political crisis. If economics is the heart of society, politics is its brain. In the same way, the political crisis in Africa arose out of issues relating to democracy. As citizens from Africa and political science researchers, we could not ignore this 
situation. Then we gave ourselves the duty to make a modest contribution. Our motivation is firstly to have a better analysis of the situation in order to make concrete proposals. Secondly, we want to give hope to those who no longer believed in the possibility of the rise of Africa. It is clear that hope is the backbone of possibility in the sense that its absence makes the nation static and promotes laziness. Hope is the key of transcendence and the realization of dreams (Aga, 2008). So when the United States was in a deep crisis, the slogan of Barrack Obama was "yes we can". The conviction shall be associated to the action in order to reset the state machine on the way of a bright future. After identifying the challenges to overcome, the right step becomes imperative especially in the context of an emerging nation. Africa is a great continent according to its history and must preserve this prestige. Undoubtedly, the challenges of democracy in Africa are indeed surmountable. The main message conveyed by this work is hope.

In this paper, after a brief conceptual analysis of democracy, we will outline the issues related to democracy in Africa, common problems and some suggestion of solutions.

\section{What Is Democracy?}

Etymologically, democracy comes from two Greek words namely DEMOS meaning people and CRATOS or CRATEIN meaning power. Thus in a simplistic way democracy is conceived as the power of people (Buccola, 2016). At this point, the first problem of interpretation arises. What is people's power? Must we understand that the people themselves lead or no longer recognize the authority of an individual?

People's power means the power designed with the people, for the people and by the people. People's participation in major decisions is obvious in a democracy. In other words, the people choose their leaders and submit to them willingly; chooses its laws and agrees to comply willingly. Far from being an opportunity to let go and let it go; Democracy is a regime that is exercised with responsibility. It is in this sense that we must understand the meaning of the contract which Rousseau mentioned in the SOCIAL CONTRACT (Medina, 1986). Democracy refers to the maturity of the people who self-discipline with the belief that "If everyone does what he likes, everyone will do what displeases others (Rousseau, More, Bacon, \& Campanella, 1901)”.

\section{The Main Problems of Democracy in Africa}

\subsection{Act of Violence}

Violence is a problem in the measure that it is contrary to democratic values. As we have previously noted, democracy is a flexible and tender regime. Just as we recognize the tree by its fruits, in the same way a political system is described by its nature. As violence is non democratic, then it calls into question the value and credibility of African democracy. Generally democracy is established and exercised in violence in Africa. Since the extension of democracy in the continent in the 90s, the lords of war become the new expansionists of democracy. Dictatorial regimes were overthrown by either rebellion or by genocide or by the popular uprising sponsored by invisible hands (Rwanda. National Commission for the Fight against Genocide, 2011). In one way or another, the practice of democracy is full of violence in Africa. 


\subsection{Problem of Identification}

Democracy is exercised in various ways throughout the world. From The 5th century $\mathrm{BC}$ to the present day several models of democracy have emerged. After its great historical changes, democracy is well defined in the developed countries. It can be direct (a democracy in which the people take decisions), Semi-direct (It's the combination of the elements of direct and representative democracy), Representative (One form of democracy in which citizens express their will through elected representatives who vote the law and control the government), Participatory (It is based on strengthening people's participation in political decision-making).

No matter the regime is, parliamentary or presidential, regardless of whether it is exercised with democratic values, In Africa, in many countries we still have a funny democracy. The regime is at the same time oligarchic, aristocratic, dictatorial, monarchy. We have a tinted democracy, multicolored, unstable, and inadequate. This is why it is difficult to quote an African country as a model of democratic practice (Ottaway, 1997).

\subsection{The Multiple Numbers of Political Parties}

The number of political parties is increasing year by year in Africa. This problem, first, makes the choice difficult for peaceful citizens, and secondly, it is an obstacle to the development of political parties themselves (Connolly \& Finlayson, 2010). Politicians use propaganda to search for militants. The lack of vision and society program inevitably immerses political actors in bellicose rhetoric and separatist speeches. Instead of gathering people, politics divides them into antagonistic groups who are motivated by hatred and revenge. The merging and splitting of political parties become routine. The plethora of political parties is an obstacle to credible political debate. The opposition in Africa is composed by the defeated candidates and embittered who do not have their share of the cake to be shared. This is why it is difficult to find a sentinel opposition which denounces objectively the slippage of the ruling party.

\subsection{The Problem of Adaptation}

Democracy as we practice it is foreign to our societal values (Wonkeryor, 2000). It came with Western ideology which we are forced to learn and comply. African political scientists have not provided enough effort to frame democracy with the realities of our societies. We are a community oriented society focused on costumes values and traditional practices (Obafemi, Babatunde, \& Bodunde, 2003).

Most Western societies are individualistic and modern with extensive notions of freedom. When trying to conform to Western democracy with its processions, we see ourselves stumbling in social contradictions more or less complicated to be solved by a single political speech. We are different historically and sociologically, for example about a word misused against an individual can relate all his tribe. There is a saying which quotes that: "Do not go to the market because you see our neighbor going; because if you go the same way, you will not return the same way." Such is the situation of Africa with imported democracy. The Selfish character of our democracies greatly opens the door to corruption. The politicians make extravagant spending to recover 
later once in power. This system automatically favors the wealthy at the expense of candidates belonging to the middle class. The fight against corruption is just a campaign password. No African head of state can fight against corruption in these forms of imported democracies. Trying to fight against corruption in these circumstances would be to "look for a black cat in a dark room".

\section{Some Common Problems Related to African Democracy}

\subsection{The Lack of National Integration}

It is true that the demarcation of borders has created too many problems to African. Because opposing kingdoms were joined together by force without any reconciliation project (Habeeb, 2007). Unfortunately, the young states were more concerned about the economic situation than social cohesion (homogeneity of citizens). In many Countries, the military regimes, coups were more related to issues of ethnicity than economic crisis. We have believed that democracy would end to this, but unfortunately it sparked panoply of rebellion and civil war (Habeeb, 2007). When you give the opportunity to people, who are living together by force, to choose among them leader by love, it becomes an equation to solve with several unknown variables. The overwhelming majority of African states are multinational like the United States, with several ethnic groups. Unlike the United States working for centuries to develop an American ideology; African states are divided and venture into the split. In their article published in open journal of philosophy, Odike, E. A., Faga, H. P., \& Nwakpu, I. W. (2016) mentioned "Electoral campaigns in Nigeria are often fraught with endemic problems, which are compounded by poor communication systems. They featured high affectivity fashioned on ethnic sentiment. This emotionalism is radiated through newspapers in urban areas by radio and at open-air rallies in rural areas" (Odike, Faga, \& Nwakpu, 2016).

\subsection{The Lack of Political Vision}

So far, Africa is mired in the politics of the belly. But normally politics target the sustainable and stable development of a given society. By development we mean the political, physical, intellectual, material and financial expansion of the citizens. It is therefore to increase the national wealth, to improve the well-being of the majority of citizens, guarantee their freedom, and strengthen their economic security. That is why in the democratic system, candidates are expected to present a draft of social development plan. Now if you talk about development you are necessarily talking about organization. Social development is a community affair in the sense that people associate their potential to achieve the common goal or common area of interest to all. In his conception of society, Aristotle wrote (Barnes, 2016): "Man is a political animal” Politics finds its essence in the community and we cannot deny it. In his book entitled laws, Plato believes that one the purpose of politics is to make men better. This means that politics should promote education and training of individuals (Schofield, 2006).

Thomas M. Magstadt defines politics as a process by which a community chooses its leaders and gives them the power to make decisions, take actions to achieve the common purpose and resolve conflicts within the community (Magstadt, 2006). This definition 
refers to more democracy and monarchy than dictatorship. But one aspect of this definition is a universal value: the purpose of politics is the realization of the general interest to the entire community. This is of paramount importance when it comes to politics. This perception confirms the Aristotelian conception of politics, namely the principle of living in community.

\section{Solutions to the Problems of Democracy in Africa}

\subsection{Ideological and Political Training}

As a military without political and ideological training is a potential criminal according to Thomas Sankara, I also think a policy without ideological and political education is an opportunistic adventurer. The policy is not a hazardous activity that we learn in the process. It is learned and exercised in an intelligible way. Africans need large schools are taught politics (Bates, Mudimbe, \& O’Barr, 1993). Africans must produce political scientists for Africa political designs compatible with the realities of the continent. 5 centuries before the birth of Jesus, Plato said that the policy should not aim to conquer power because politics should be the result of skills, knowledge of good and justice.

Politicians are greedy of power in Africa to the point they are able to push the population to endless civil wars that paralyze States. The training helps us to leave the politics of the belly (the consumer policy) for the constructive policy, designed and maintained with nationalist convictions (Mudimbe, 1972).

\subsection{Separate Politics from Religion}

Religion and politics are two areas in which it seeks to regulate the lives of men in society (Murphy, 2011). In human history, they were mixed in various places on the earth either for the advantage of politics or for the benefit of religion. We understand that people combine religion and politics for interest purpose. Politics and religion are two forms complex ideology that arouse the emotions of people and cause them to act out of instinct. So the combination is as dangerous as any devastating weapon (Meijer, 2009). It is obvious that religion can make people kind, humble to the point that it will be easier to lead them. In this logic politics will find it easier in the governance of citizens. The main difference between religion and politics lies at two levels including their nature and objectives. If we consider the aspect of nature, they are two antagonistic types of power of which is spiritual and the temporal. This is what gives them conflicting objectives. Religion is beyond the political aims and terrestrial life (Material development and human concern financial policy). Policy concern is the present while religion deals with the future, i.e. after death. The policy principles come from the right, while those of religion are dictated by God. As a form of social consciousness and may lead to ideological conflicts unmanageable.

The mode of operation differs from one area to another. So religion and politics can be only at the best complementary. Religion cannot dictate to the politics its principles otherwise it will damage the freedom of conscience (Vatter, 2011). In a given society, men have different religious beliefs. In this context, which religion will impose its principles? So this circumstance leads to division, whereas the purpose of politics is to bring citizens together. Given that politics and religion have different purposes, they cannot 
mix. Religion and politics by mixing mutually create damage. For example, in the US, 19th Century, this phenomenon has opposed the revival churches and traditional churches; Protestant churches against Catholic churches for years (Green, Rozell, \& Wilcox, 2003). As a consequence, many faithful believers have stopped going to church and many citizens no longer went to the polls to vote (Sundkler, Beyerhaus, \& Hallencreutz, 1969).

\subsection{Having a Competent Foreign Policy}

The diplomacy should be seen as an instrument which is used for two goals: defend the interest of one country in another and establish the preconditions of permanent peace. The role of diplomacy is so important among nations because it facilitates cultural interexchange and lets people living together in peace. The diplomacy works well if there is mutual reliance between those who are in relationship. The wisdom and the behavior of a diplomat are so important in the cooperation between two countries. We have said previously that the confidence is the corner stone in diplomatic relations. Without mutual reliance there is no hope to build something strong. But there is something to know about trust like confidence does not force, it deserves. One big and common problem with African diplomacy is the lack of trust. Not because other under look African's diplomatic representatives but because of the structure and the way diplomatic representatives have been chosen. We can see some major crisis as:

- The standard of choice: Henry Wotton describes the diplomat as an honest man sent abroad to lie for his country (Morgenthau, 1960). That means from the beginning the diplomat deserve the trust of those who choose him. Morgenthau noticed that through the functions of the diplomat, the prestige in which his nation is held abroad is tested and the prestige with which his own nation regards the country to whose government he is accredited is tested too. Just to emphasize that the role of the diplomat should not be neglected. Most of time African's government send abroad those who are a threat for their regime. When the representative is not serious or the majority of the foreign stuff is not serious, there is no luck to deserve the trust of the country which accredited them. The foreign politics is as important as domestic policy. Somebody should not be chosen as diplomat in order to send him far away from the government, but someone who can work for the interest of the government. Far more, the domestic conflict of African countries also blocs the effectiveness of diplomacy. We have noticed that the image of the country is appreciated abroad through diplomacy. When the image of the country is misperceived, how diplomacy can attain its goals? No way! So leaders should better think about the Peace building as priority in their agenda.

- The focus: The African's diplomacy is focused on begging than building a partnership. So beggary is the most important action than to consolidate a strong and long relationship. This attitude lets the diplomacy getting more and more weak and ineffective. We said previously that the two main goals of diplomacy are protect the interest of one nation and establish peace among nations. These mains goals are inexistence in African's diplomacy. That's why since independence up to now African leader travel to berg or send diplomat to beg from. In this kind of situation, equality 
is not possible but superiority and inferiority. Finally those who are giving their money are allowed to decide for our domestic affairs. In the world politics nations are going forward in competition. The foreign policy of African countries is similar to a game of prostitution. They accept everything because of money and there are submitted to others as a sheep to his owner. Anywhere we saw a country build his future in begging. This focus is wrong and dangerous for the image of the country. People are easily tired with those who beg all the time. The wise of Mali say: we cannot help toad to climb the tree. That means in the impossible there is no obligation. So African's must stop relying on others if they want to change the sight of Africa. The changing of mentality should be the priority because the spirit of poverty is worse than poverty itself. Then the focus of diplomacy will no more be beggary.

As Morgenthau lets us know, the task of diplomacy is fourfold: Determine its objectives and the means to achieve them; evaluate the objectives of other nations; extension of these objectives and their compatibility and employ the appropriate means to attain its objectives. Morgenthau shows three essential means: persuasion, compromise and threat of force (Morgenthau, 1960). If you look at these tasks and the means to achieve them, it's easy to remark that African's diplomacy is sick and need to be healed. If the patient hides his disease, treatment becomes difficult. Just to say that African's must acknowledge they own problems then they can expect the solution. So far we continue with diplomacy focused on begging from other nations. This opens the door to many ideologies that are not favorable to maintaining stability in sub-Saharan Africa. Hand tends even to the devil to call for help after. We could have avoided a lot of problems in Africa if we had a vigilant and visionary foreign policy. No country can develop from donations. From the independence to the present day, Africa would have become a paradise on earth. Unfortunately we do now the tail on the list of Heavily Indebted and Poor Countries.

\section{Conclusion}

The long march from Africa to democracy is sometimes challenging, sometimes unrealistic dream. It is a challenge because we are already committed and we have to win the bet. It is a utopia to the extent that our realities are contrary to democratic principles. It is especially in sub-Saharan Africa, East Africa and some Gulf countries that democracy leads into a lot of trouble. The reasons are the same: the unpreparedness of the spirits and the fact of burning stages. Democracy came to us with a mind that is not ours, with values that are at odds with our societal values. The tribal and provincials wars are related to the implementation of democracy weakens our states in terms of human resources but also material resources. Africa does not need democracy to buy at the price of his blood. The implementation of democracy is a process, not an imposition. Africans should not ignore the fact that those who impose democracy have not adhered to democracy through force. So why do Africans have to pour out blood and destroy their infrastructure for nothing?

\section{Acknowledgements}

We want to appreciate Saviour Ayertey Nubuor for his assistance. 


\section{References}

Aga, K. (2008). Where Hope Takes Root: Democracy and Pluralism in an Interdependent World. Vancouver: Douglas \& McIntyre.

Barnes, J. (Ed.) (2016). Aristotle's Politics: Writings from the Complete Works. (With an introduction by Melissa Lane)

Bates, R. H., Mudimbe, V. Y., \& O’Barr, J. F. (1993). Africa and the Disciplines: The Contributions of Research in Africa to the Social Sciences and Humanities. Chicago, IL: University of Chicago Press.

Buccola, N. (2016) Abraham Lincoln and Liberal Democracy. (Essays written as part of a 2014 conference hosted by Linfield College on Abraham Lincoln are collected in Abraham Lincoln and Liberal Democracy)

Connolly, W. E., \& Finlayson, A. (2010). Democracy and Pluralism: The Political Thought of William E. Connolly. London; New York: Routledge.

Green, J. C., Rozell, M. J., \& Wilcox, C. (2003). The Christian Right in American Politics: Marching to the Millennium. Washington, DC: Georgetown University Press.

Habeeb, W. M. (2007). Civil Wars in Africa. Philadelphia, PA: Mason Crest Publishers.

Magstadt, T. M. (2006). Understanding Politics: Ideas, Institutions \& Issues (7th ed.). Belmont, CA: Thomson Higher Education.

Medina, J. (1986). Jean-Jacques Rousseau, Du Contrat Social. Paris: Magnard.

Meijer, R. (2009) Global Salafism: Islam’s New Religious Movement.

Morgenthau, H. J. (1960). Politics among Nations: The Struggle for Power and Peace (3d ed.). New York: Knopf.

Mudimbe, V. Y. (1972). Autour de "la nation": Leçons de civisme: Introduction. Paris: Editions du Mont Noir; Diffusion à l'étranger, Libr. Saint Germain des Prés.

Murphy, A. R. (2011). The Blackwell Companion to Religion and Violence. Chichester, West Sussex; Malden, MA: Wiley-Blackwell.

Obafemi, O., Babatunde, S. T., \& Bodunde, C. (2003). Criticism, Theory and Ideology in African Literature. Ilorin Nigeria: Haytee.

Odike, E. A., Faga, H. P., \& Nwakpu, I. W. (2016). Incorporation of Fundamental Objectives and Directive Principles of State Policy in the Constitutions of Emerging Democracies: A Beneficial Wrongdoing or a Democratic Demagoguery? Beijing Law Review, 7, 267-277. http://dx.doi.org/10.4236/blr.2016.74025

Ottaway, M. (1997). Democracy in Africa: The Hard Road Ahead. Boulder, CO: L. Rienner Publishers.

Rousseau, J.-J., More, T., Bacon, F., \& Campanella, T. (1901). Ideal Empires and Republics; Rousseau's Social Contract, More's Utopia, Bacon's New Atlantis, Campanella's City of the sun (Autograph éd. de luxe.ed.). Washington \& London: M. W. Dunne.

Rwanda. National Commission for the Fight against Genocide (2011). 16 Years after the Genocide Perpetrated against Tutsi (1994-2010): Handling Its Consequences $=16$ ansaprès le génocideperpétré contre les tutsi (1994-2010): Gestion de sesconséquences. Kigali: Repubulikay’u Rwanda, National Commission for the Fight against Genocide.

Schofield, M. (2006). Plato: Political Philosophy. Oxford; New York: Oxford University Press.

Sundkler, B., Beyerhaus, P., \& Hallencreutz, C. F. (1969). The Church Crossing Frontiers. Essays on the Nature of Mission. In Honour of Bengt Sundkler. Lund: Gleerup.

Vatter, M. E. (2011). Crediting God: Sovereignty and Religion in the Age of Global Capitalism. New York: Fordham University Press. https://doi.org/10.5422/fso/9780823233199.001.0001

Wonkeryor, E. L. (2000). American Democracy in Africa in the Twenty-First Century? Cherry Hill, NJ: Africana Homestead Legacy Publishers. 
Submit or recommend next manuscript to SCIRP and we will provide best service for you:

Accepting pre-submission inquiries through Email, Facebook, LinkedIn, Twitter, etc. A wide selection of journals (inclusive of 9 subjects, more than 200 journals) Providing 24-hour high-quality service

User-friendly online submission system

Fair and swift peer-review system

Efficient typesetting and proofreading procedure

Display of the result of downloads and visits, as well as the number of cited articles Maximum dissemination of your research work

Submit your manuscript at: http://papersubmission.scirp.org/

Or contact ojps@scirp.org 